\title{
Endovascular treatment of popliteal artery aneurysm
}

\author{
Fernando Thomazinho'; J ose Manoel da Silva Silvestrel'; Wander Eduardo Sardinhal'; \\ Fernando Motta'I'; I gor Schincariol Perozin'V; Domingos de Morais Filho"I \\ 'Physician, Vascular Surgery Service, Hospital Universitário Regional do Norte do Paraná (HURNP), \\ Londrina, PR, Brazil. \\ "PhD. Professor, Vascular Surgery, HURNP, Londrina, PR, Brazil. \\ II'Resident, Vascular Surgery Service, HURNP, Londrina, PR, Brazil. \\ IV Medical student, Universidade Estadual de Londrina (UEL), Londrina, PR, Brazil.
}

Correspondence

J Vasc Bras. 2008; 7(1):38-43.

\begin{abstract}
Background: The most commonly occurring aneurysms in the periphery are those involving the popliteal artery. They comprise $70-80 \%$ of all such aneurysms. Conventional aneurysm repair consists of either opening the aneurysm sac and interposing a bypass graft or aneurysm ligation combined with bypass grafting. Endovascular treatment is an alternative to conventional repair.

Objective: To evaluate use of stent graft in the endovascular treatment of popliteal artery aneurysms. Methods: We analyzed 17 male patients; of these, 11 were treated with endovascular stent graft, using Hemobahn and Viabahn stent grafts.

Results: One patient had pseudoaneurysm in the immediate postoperative period. Among late complications, one patient had distal endoleak after 7 months, and there was stent graft occlusion in another patient. The remaining nine patients had satisfactory Doppler ultrasonography control at 20 months, which resulted in a primary patency of $90 \%$ over mean follow-up time of 27 months.

Conclusion: Endovascular repair of a popliteal artery aneurysm is feasible and has some advantages compared with the open treatment, such as shorter hospital stay and recovery.
\end{abstract}

Keywords: Peripheral aneurysms, popliteal artery aneurysm, endovascular treatment.

\section{RESUMO}

Contexto: Dos aneurismas periféricos, o da artéria poplítea é o mais freqüente, correspondendo a 70 a $80 \%$ dos casos. O tratamento cirúrgico convencional consta de exclusão do aneurisma e interposição de enxerto em ponte ou de ressecção parcial ou total do aneurisma e reconstrução arterial com enxerto em continuidade. O tratamento endovascular surgiu como uma alternativa ao reparo convencional. 
Objetivo: Avaliar o uso de endoprótese para o tratamento endovascular do aneurisma de artéria poplítea.

Metodologia: Num total de 17 pacientes, todos do sexo masculino, 11 foram tratados por técnica endovascular, utilizando-se próteses Hemobahn e Viabahn.

Resultados: Um paciente apresentou pseudo-aneurisma no pós-operatório imediato. Dentre as complicações tardias, um paciente apresentou endoleak distal da prótese após 7 meses, e houve oclusão da endoprótese em outro. Os nove pacientes restantes apresentaram controle de eco-Doppler satisfatório aos 20 meses, resultando em uma perviedade primária de $90 \%$ em um período médio de 27 meses de seguimento.

Conclusão: O tratamento endovascular para aneurisma de artéria poplítea é factível e apresenta algumas vantagens em relação ao tratamento aberto, como menor tempo de internação e de recuperação.

Palavras-chave: Aneurisma periférico, aneurisma da artéria poplítea, tratamento endovascular.

\section{Introduction}

Popliteal artery aneurysms (PAA) are the most frequent of all peripheral aneurysms, accounting for 70 $80 \%$ of cases. They usually occur in men over 65 years, and $50 \%$ of them are bilateral. Most patients are symptomatic in initial clinical presentation. Conventional PAA repair consists of either opening the aneurysm sac and interposing a bypass graft or aneurysm ligation combined with bypass grafting.

Over the past years, endovascular surgery has become an alternative to open repair, since it offers some advantages when compared to open surgery: less blood loss, faster recovery and early hospital discharge. $^{1}$

This study aimed at assessing use of stent graft in endovascular treatment of PAA.

\section{Method}

From J anuary 2005 to October 2006, 17 patients with PAA were assessed. They all had aneurysm with diameter $>2 \mathrm{~cm}$ and distal proximal neck $>1 \mathrm{~cm}$.

Exclusion criteria were patients younger than 50 years, poor distal arterial bed (absence of at least one continuous tibial artery until the foot), patients contraindicated for platelet antiaggregation and/or symptoms of venous and/or nervous compression, and presence of acute ischemia. Eleven patients (Table 1) were selected for endovascular treatment, and three were symptomatic (episode of distal embolization). All patients selected for endovascular treatment had at least one patent continuous tibial artery until the foot. The remaining six patients were excluded due to acute ischemia.

All patients were male, mean age 64 years (55-72). Aneurysm diameter and mean extension were respectively $25.8 \mathrm{~mm}(22.9-32.1)$ and $72.7 \mathrm{~mm}(55.3-110)$.

Of patients submitted to treatment, three had bilateral PAA, and two had been submitted to open surgery in the contralateral limb; one was not submitted to surgery because the aneurysm in the other limb was small $(<2 \mathrm{~cm}$ in diameter) and without parietal thrombi.

Three limbs required two stent grafts due to aneurysm length, and in three patients the stent graft was extended beyond the articular interline. Color-flow Doppler was performed for quantification of 
aneurysm extension and diameters. Later, arteriography was performed to assess proximal and distal arterial bed.

Materials used were Hemobahn and Viabahn stent grafts (W.L. Gore \& Associates, Inc., Flagstaff, Ariz). These stent grafts consist of several nitinol stents internally covered by a thin PTFE layer. Hemobahn was available in a diameter of $9-13 \mathrm{~mm}$ and 5,10 and $15 \mathrm{~cm}$ in extension, using a $0.025^{\prime \prime}$ guide wire and a release system from proximal to distal. Viabahn is available in $6-8 \mathrm{~mm}$ diameters, 0.035 " guide wire and release system from distal to proximal.

The common femoral artery was approached by dissection under local anesthesia, with passage of a 9$12 \mathrm{Fr}$ sheath using anterograde approach, except for a selected case in which the procedure was performed exclusively using percutaneous technique, since it was a $9 \mathrm{Fr}$ sheath. The patients were given 5,000 IU venous heparin. In choice of stent graft, mean overdimensioning was approximately $20 \%$. In cases that required more than one stent graft for repair, overlapping between grafts was $2 \mathrm{~cm}$. Ideal neck, both proximal and distal, was defined as that equal or higher than $2 \mathrm{~cm}$ in extension. However, if the stent graft distal fixation area coincided with the articular interline, there would be risk of stent fracture or graft occlusion, which would not occur if that area was located $2-3 \mathrm{~cm}$ above the interline. In cases in which the distal fixation area was located at the interline level, we chose to go $2-3 \mathrm{~cm}$ beyond the articular line.

The patients were given platelet antiaggregation with clopidogrel $75 \mathrm{mg} /$ day for 30 days and ASA 200 $\mathrm{mg} / \mathrm{day}$.

Clinical patency criteria were palpable distal pulses and/or maintanence of ankle-brachial index ( $A B I)$ or $A B I$ reduction $<0.15$ relative to the postoperative period. Color-flow Doppler follow-up was performed 30 days after the procedure, and at every 3 months thereafter, or before, in case patients presented at symptom.

Table 1 - Population

\begin{tabular}{ll}
\hline Number of patients & 11 (all male) \\
Age (years) & $55-72$ (mean: 64,27$)$ \\
Diameter (mm) & $22.9-32.1$ (mean: 25,8$)$ \\
Extension $(\mathrm{mm})$ & $53.3-110$ (mean: 72,7$)$ \\
Morphology & \\
$\quad$ Saccular & $45 \%(5)$ \\
Fusiform & $55 \%(6)$ \\
Bilaterality & $27 \%(3)^{*}$ \\
\hline
\end{tabular}

* Two patients had been treated by open surgery, and one was asymptomatic and had aneurysm $<2.0 \mathrm{~cm}$.

\section{Results}

At the 20-month follow-up, nine patients had satisfactory control confirmed by color-flow Doppler ultrasound. They were all followed at every 3 months. The three patients who had embolization (occlusion of a leg artery) were not submitted to embolectomy before stent graft placement, since they had at least one continuous artery until the foot and did not have acute ischemia.

Among early complications, one patient had pseudoaneurysm in the immediate postoperative period. In this case, the procedure was performed by percutaneous technique through anterograde puncture using a $9 \mathrm{Fr}$ sheath. The procedure was performed uneventfully, but the patient, already at the ward, had sudden bulging of the inguinal region and hypotension, which characterized a voluminous 
pseudoaneurysm in the common femoral artery, associated with hemodynamic instability, which required surgical intervention. Another patient had superficial surgical site infection, successfully treated by oral antibiotic therapy.

Among late complications, one patient had distal embolization in leg arteries due to aneurysm sac refilling caused by distal endoleak. There was migration of the stent graft distal extremity into the aneurysm sac; this patient was treated by thromboembolectomy associated with femoropopliteal graft. Another patient had occlusion repair at 9 months, when the stent graft went beyond the articular interline; this patient was then submitted to femoropopliteal bypass. There were no deaths during the study (Table 2 ).

Table 2 - Results

\begin{tabular}{|c|c|}
\hline Number of stent grafts & 14 (three patients used two stent grafts each) ${ }^{*}$ \\
\hline Infrapopliteal graft & $3(27 \%)$ \\
\hline Hospitalization time (days) & $2-7$ (mean: 2,63 ) \\
\hline Follow-up time (months) & $20-36$ (mean: 27,42 ) \\
\hline \multicolumn{2}{|l|}{ Complications } \\
\hline Pseudoaneurysm & $9 \%(1)$ \\
\hline Occlusion & $9 \%(1)^{t}$ \\
\hline Surgical site infection & $9 \%(1)$ \\
\hline Endoleak & $9 \%(1)^{7}$ \\
\hline Primary patency (20 months) ${ }^{\dagger}$ & $90 \%$ \\
\hline
\end{tabular}

Mean hospitalization time was 2.63 days. The only patient who needed transfusion had pseudoaneurysm and the longest hospitalization time.

Of a total of 11 limbs, one patient occluded at 9 months, and another was excluded from the study due to endoleak. The remaining nine patients were followed for 20 months and there was an occlusion at 9 months. Patency curve was as follows: of the 11 patients, one left the curve, since he had endoleak (in the patency curve, endoleak cases are not considered as occlusion outcome, but leave the curve as if they were loss of follow-up, for example); thus, at 20 months we had follow-up of 10 patients ( 11 minus one patient with endoleak, which was treated by surgery) and we only has one occlusion outcome, which resulted in $90 \%$ patency $(9 / 10)$ (Figure 1 ). 


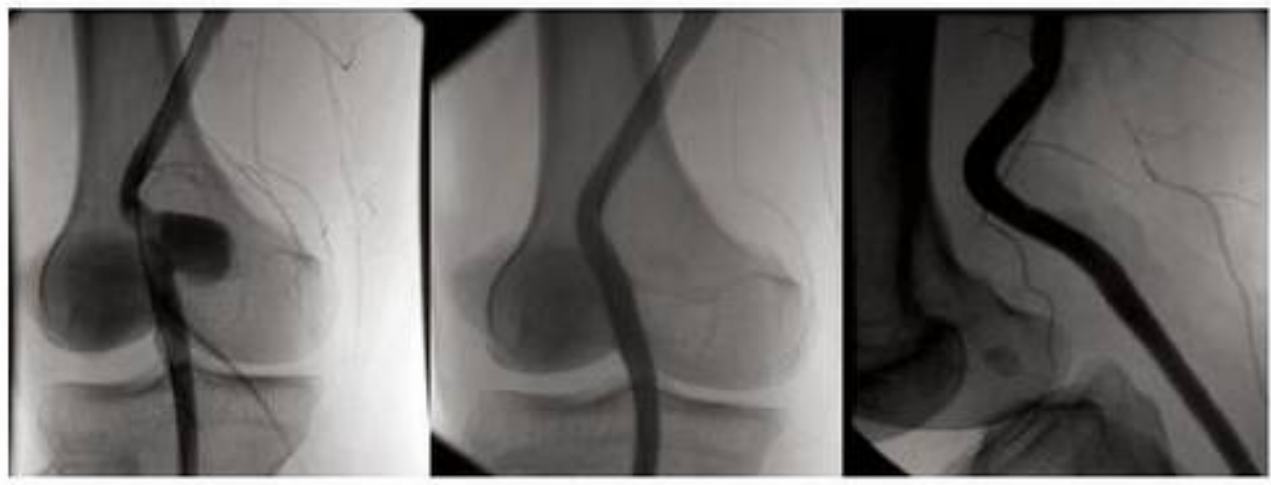

Figure 1 - Angiography showing aspect before and after the procedure.

\section{Discussion}

Clinical manifestations of PAA include acute arterial thrombosis, distal embolization, venous and/or nervous compression and rupture, which is a rare complication. 2 Most PAA can be clinically diagnosed when diameter is larger than $3 \mathrm{~cm} \cdot \frac{3,4}{\mathrm{In}}$ our series of patients, most PAA were fusiform, which is in agreement with other studies. $\underline{5}$

Presence of PAA can be suspected by physical examination when there is increased pulsatility in the popliteal fossa. Vascular ultrasound is the most useful examination to confirm diagnosis, since it not only assesses amount of intraluminal thrombus, aneurysm and unaffected artery diameter, aneurysm thrombosis and adjacent vein compression, but also excludes entities such as Baker's cyst. Angiographic tomography, magnetic resonance and arteriography can be performed for surgical planning, with the aim of assessing proximal and distal arteries. $\underline{6}$ Some authors consider angiographic tomography as the best examination for that purpose. $\underline{7}$

Traditionally, symptomatic or asymptomatic PAA with diameter larger than $2 \mathrm{~cm}$ should be surgically treated. Aneurysms smaller than $2 \mathrm{~cm}$ in diameter and without parietal thrombi are conservatively managed and deserve serial follow-up. Elective repair had limb loss rate $<5 \%$ in a 10 -year follow-up. $\underline{3}$

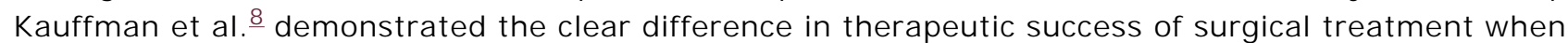
the patient is asymptomatic, compared to those who had already have complications. The main and most feared complication is acute arterial occlusion due to aneurysm thrombosis, with high risk of limb loss (40-50\%),, , $9-11$ even using proper treatment.

The technique for treatment of popliteal artery aneurysm involves aneurysm ligation to prevent embolization associated with graft and to restore arterial continuity, usually performed through medial access, which also facilitates removal of the great saphenous vein as arterial substitute. $\frac{10,12}{12}$ However, for large aneurysms or for those that cause compression of adjacent structures, posterior access is preferred, with the patient in the prone position for decompression, and the small saphenous vein can be removed and used as interposed graft.

Primary patency rate is $69-75 \%$ in 5 years, and limb salvage rate is $75-100 \% .4,13-15$ Galego et al. $\underline{5}$ obtained a $90.6 \%$ success rate for open treatment using ligation and saphenous graft in 15 out of 22 popliteal artery aneurysms submitted to treatment. Huang et al. $\frac{16}{16}$ published their results of 358 popliteal artery aneurysms treated by open surgery. With mean follow-up of 4.2 years, they found primary and secondary patency rates of 76 and $87 \%$, respectively. Great saphenous vein bypass ( 85 and $94 \%$ ) was better than PTFE bypass ( 50 and $63 \%$ ). These results are similar to previous studies on open treatment of popliteal artery aneurysms. $\underline{17,18}$ 
Endovascular treatment has recently been an alternative to open repair, especially for high surgical risk patients. Marin et al. $\frac{19}{19}$ were the first to perform endovascular repair of PAA. Since then, due to advances in materials, patency rates have significantly increased. A theoretical disadvantage of this technique is the anatomic region, which is located in a posterior position in relation to the knee articulation; therefore, implanted graft is submitted to constant physical stress and higher risk of occlusion.

Galego et al., $\underline{5}$ in the study mentioned above, treated two patients using the endovascular technique; in one of the patients, Palmaz P294 ${ }^{\circledR}$ stent with PTFE was used; in the other patient, Corvita ${ }^{\circledR}$ was used. The first case had occlusion in the immediate postoperative period, requiring surgical repair. Kauffman et al.,, in two cases treated with the endovascular technique, reported occlusion in both cases, one at 3 and another at 11 months after the treatment; however, both of them had proper circulatory compensation, with no need of additional treatment. In Brazil, Medeiros et al. $\underline{20}$ have recently reported endovascular treatment using Hemobanh and Viabanh ${ }^{\circledR}$ in two patients with bilateral popliteal artery aneurysm, both with present distal pulses at hospital discharge.

Howell et al. $\underline{21}$ reported stent graft thrombosis in $31 \%$ at 12 months in a total of 13 aneurysms treated by Wallgraft stents (Boston Scientific, Natick, Mass)..$\underline{4}$ Tielliu et al. $\underline{22}$ found primary and secondary patency rates of 77 and $87 \%$ at 2 years when assessing 57 cases treated by Viabanh, a slightly inferior result compared to open repair. Antonelo et al., 1 in a comparative study with conventional treatment, found primary and secondary patency of 87 and $100 \%$, respectively, for endovascular repair, at 24 months, with limb salvage rate of $100 \%$.

As to limb salvage rates, Aulivola et al. $\underline{23}$ demonstrated better indexes when the PAA is treated electively, compared to emergency treatment. Even if graft and/or stent graft patency is not excellent in the long term, if it is possible to maintain it patent for at least 1 year, limb salvage rates can be increased. $\underline{14}$

More recently, Curi et al. $\frac{24}{2}$ reported primary and secondary patency rates of 83 and $100 \%$ at 24 months, respectively, when assessing 15 cases of PAA treated by endovascular technique.

Use of platelet antiaggregation and enhancement of materials improve patency rates. The material used in the present study has the advantage of being flexible. This is extremely important, because the popliteal artery is located in an area of constant movement, which predisposes to fracture of used devices.

\section{Conclusions}

To date, studies comparing results of endovascular and conventional treatment were mostly retrospective and included small series. Therefore, further prospective studies comparing open and endovascular treatment are needed.

Endovascular treatment has been a feasible alternative for patients at increased surgical risk. We still have to know, based on longer follow-up studies, if this is also the treatment of choice for patients at low surgical risk, considering that this type of treatment has little interference with a further open treatment, in case of endovascular treatment failure.

Endovascular treatment for PAA is feasible and has some advantages compared to the open treatment, such as shorter recovery and hospitalization time.

\section{References}


1. Antonello M, Frigatti P, Battocchio P, et al. Open repair versus endovascular treatment for asymptomatic popliteal artery aneurysm: results of a prospective randomized study. J Vasc Surg. 2005; 42: 185-93.

2. Lowell RC, Gloviczki P, Hallett JW Jr., et al. Popliteal artery aneurysms: the risk of nonoperative management. Ann Vasc Surg. 1994; 8:14-23.

3. Dawson I, van Bockel JH, Brand R, , Terpstra JL. Popliteal artery aneurysms: long term follow-up of aneurysmal disease and results of surgical treatment. J Vasc Surg. 1991;13:398-407.

4. Roggo A, Brunner U, Ottinger LW, Largiader F. The continuing challenge of aneurysms of the popliteal artery. Surg Gynecol Obstet. 1993; 177:565-72.

5. Galego GN, Silveira PG, Bacega NR, et al. Apresentação clínica e tratamento cirúrgico na doença aneurismática da artéria poplítea. Angiol Cir Vasc. 2002; 11:119-25.

6. Morris-Stiff G, Haynes M, Ogunbiyi S, et al. Is assessment of popliteal artery diameter in patients undergoing screening for abdominal aortic aneurysms a worthwhile procedure. Eur J Vasc Endovasc Surg. 2005; 30: 71-4.

7. Ebaugh J L, Matsumura JS, Morasch MD, Pearce WH, Nemcek AA, Yao JS. Morphometric analysis of the popliteal artery for endovascular treatment. Vasc Endovascular Surg. 2003;37:23-6.

8. Kauffman P, Puech-Leão P. Tratamento cirúrgico do aneurisma da artéria poplítea: experiência de 32 anos. J Vasc Bras. 2002; 1:5-14.

9. Dawson I, Sie RB, van Bockel JH. Atherosclerotic poplíteal aneurysm. Br J Surg. 1997; 84:293-9.

10. Elsman BH, van Rijn AB. In-situ saphenous vein bypass graft for popliteal artery aneurysm. Neth J Surg. 1991; 43: 14-6.

11. Galland RB, Magee TR. Management of popliteal aneurysm. Br J Surg. 2002;89:1382-5.

12. Szilagyi DE, Schwartz RL, Reddy DJ. Popliteal arterial aneurysms. Arch Surg. 1981;116:724-8.

13. Jones WT 3rd, Hagino RT, Chiou AC, Decaprio JD, Franklin KS, Kashyap VS. Graft patency is not the only clinical predictor of success after exclusion and bypass of popliteal artery aneurysms. J Vasc Surg 2003; 37:392-8.

14. Sarcina A, Bellosta R, Luzzani L, Agrifoglio G. Surgical treatment of popliteal artery aneurysm. A 20 year experience. J Cardiovasc Surg (Torino). 1997; 38: 347-54.

15. Borowicz MR, Robison J G, Elliott BM, Brothers TE, Robinson CK. Occlusive disease associated with popliteal aneurysms: impact on long term graft patency. J Cardiovasc Surg (Torino). 1998; 39: 137-40.

16. Huang Y, Gloviczki P, Noel AA, et al. Early complications and long-term outcomes after open surgical treatment of popliteal artery aneurysms: Is exclusion with saphenous vein bypass still the gold standard? J Vasc Surg. 2007;45:706-13.

17. Shortell CK, DeWeese JA, Ouriel K, et al. Popliteal artery aneurysms: a 25-year surgical experience. J Vasc Surg. 1991; 14:771-9.

18. Carpenter JP, Barker CF, Roberts B, Berkowitz HD, Lusk EJ, Perloff LJ. Popliteal artery aneurysms: current management and outcome. J Vasc Surg. 1994; 19:65-73.

19. Marin M, Veith FJ, Panetta TF, et al. Transfemoral endoluminal stented graft repair of a popliteal 
artery aneurysm. J Vasc Surg. 1994;19:754-7.

20. Medeiros CAF, Gaspar RJ. Correção endovascular do aneurisma de artéria poplítea bilateral. J Vasc Bras. 2006;5:303-7.

21. Howell M, Krajcer Z, Diethrich EB, et al. Wallgraft endoprosthesis for the percutaneous treatment of femoral and popliteal artery aneurysms. J Endovasc Ther. 2002;9:76-81.

22. Tielliu IF, Verhoeven EL, Zeebregts CJ, Prins TR, Span MM, van den Dungen JJ. Endovascular treatment of popliteal artery aneurysms: results of a prospective cohort study. J Vasc Surg.

2005;41:561-7.

23. Aulivola B, Hamdan AD, Hile CN, et al. Popliteal artery aneurysm: a comparison of outcomes in elective versus emergent repair. J Vasc Surg. 2004;39:1171-7.

24. Curi MA, Geraghty PJ, Merino OA, et al. Mid-term outcomes of endovascular popliteal artery aneurysm repair. J Vasc Surg. 2007;45:505-10.

\section{团Correspondence:}

Fernando Thomazinho

Av. Voluntários da Pátria, 251

CEP 86061-160 - Londrina, PR, Brazil

Tel.: (43) 3026.5254, (43) 8402.6452

Email: thomazvasc@hotmail.com

Manuscript received October 25, 2007, accepted January 22, 2008. 